\title{
ANALYSIS OF CALCULATED AND OBSERVED SETTLEMENTS OF THE SILO ON LOESS
}

\author{
Petar Santrač, Željko Bajić, Slobodan Grković, Danijel Kukaras, Ivan Hegediš
}

Subject review

This paper presents the analysis of the results of observed and calculated settlements for the silo, due to load and partial saturation of the loess. In a dry state loess has high strength and low compressibility, however, highly porous layers of loess due to saturation lose structure, reduce volume and strength extremely. This feature of loess is known as structural collapse, or hydro collapse, making it one of the meta-stable soils, which are very unfavourable in terms of foundation. During the construction of the silo, due to inadequate protection during the intense rainfall, partial saturation of the surface layers has occurred, which undermined the initial structure of the loess and caused additional settlements that were registered during the first filling of the silo. To assess the development of settlements in these changed circumstances, the settlement calculations were performed, based on the collapse potential, increase of moisture, wetting depth and available quantity of rainfall for given location according to data from the National Hydro Meteorological Institute. Prediction of the expected subsequent settlements was crucial for undertaking necessary measures in order to ensure the smooth functioning of the silo. Currently, 2,5 years from the first filling of the silo cells, the settlement growth has practically diminished and the silo is functioning smoothly.

Keywords: foundation; hydro-collapse; loess; settlement

\section{Analiza proračunskih i izmjerenih slijeganja silosa na lesu}

Pregledni članak

U radu je prikazana analiza rezultata izmjerenih i proračunskih slijeganja silosa uslijed opterećenja i djelomičnog zasićenja lesa. Les u suhom stanju ima visoku čvrstoću i malu stlačivost, međutim vrlo porozni slojevi lesa uslijed zasićenja gube strukturu i izrazito smanjuju volumen i čvrstoću. Ova osobina je poznata kao strukturni ili hidro kolaps, što ga svrstava u meta-stabilna tla, koja su vrlo nepovoljna u pogledu temeljenja. Prilikom izgradnje silosa, zbog neadekvatne zaštite tokom intenzivne kišne sezone prouzrokovano je djelomično zasićenje površinskih slojeva, što je narušilo inicijalnu strukturu lesa $i$ uvjetovalo dopunska slijeganja koja su registrirana pri prvom punjenju silosa. Da bi se procijenio razvoj slijeganja u izmijenjenim uvjetima, urađen je proračun slijeganja zasnovan na potencijalu kolapsa, porastu vlažnosti, dubini provlaživanja i raspoloživoj količini kiše za danu lokaciju prema podacima nacionalnog meteorološkog zavoda. Podatak o mogućim naknadnim slijeganjima je bio presudan za poduzimanje neophodnih mjera radi obezbjeđenja neometanog funkcioniranja silosa.Od prvog punjenja silo ćelija je prošlo oko 2,5 godine. Slijeganje je praktično prestalo a silos neometano funkcionira.

Ključne riječi: hidro-kolaps; les (prapor); slijeganje; temeljenje

\section{Introduction}

For the storage and processing of wheat, in the early 2010 , the construction of a reinforced concrete silo with auxiliary buildings, mills, storage products, parking space and roads has begun. The location of the building is 1.9 $\mathrm{km}$ south-east of Feketić, on the right side of the E-75 highway from Subotica to Novi Sad. Geographic coordinates of the location are $45^{\circ} 39^{\prime} 22,76^{\prime \prime} \mathrm{N}$ and $19^{\circ} 43^{\prime} 15,75^{\prime \prime} \mathrm{E}$, and the absolute altitude of the site is between 99,78 and 101,20 m. Morphologically the terrain is plain, with gently rolling loess plateau.

According to the structural design [1] the $17,7 \mathrm{~m}$ high silo is founded on reinforced concrete slab (mat). Contact pressure is $190,0 \mathrm{kPa}$ (self-weight $\approx 48 \%$ ). The mill is $25,5 \mathrm{~m}$ high and founded on a $30,7 \times 10,0 \mathrm{~m} \mathrm{RC}$ slab. Contact pressure is $155,0 \mathrm{kPa}$ (self-weight $\approx 59 \%$ ). Storage building for products has base dimensions of 24,0 $\times 14,2 \mathrm{~m}$ and its foundation are $6,0 \times 6,0 \mathrm{~m}$ spaced single footings.

To define the geomechanical profile [2], 8 borings with max. depth of $14,0 \mathrm{~m}$ and 2 cone penetration tests of $200 \mathrm{kN}$ capacity were conducted. Investigation work was carried out during June $\div$ July 2009. Based on site and laboratory tests, it was determined that soil profile consists of clayey loess, beneath which is a medium dense to dense fine-grained sand.

On the site, loess layer has a thickness of about 12,0 $\mathrm{m}$ and it mainly consists of silt, light brown to yellow in colour, with variable clay content and increasing sand contents close to the bottom of the layer. The grains of silt and sand are weakly bounded by clay and carbonate binder. Based on USCS, it is a low to medium plastic clay CL-CI. At a depth of $12,4 \div 12,6 \mathrm{~m}$, entering the layer of sand, the capacity of the penetrometer was exhausted. 24 hours after completion of the drill probing, the ground water level was located at a depth of $13,8 \mathrm{~m}$ bellow the ground surface.

In geological terms it is a Quaternary layer: loess and loessoidal sandy siltstone overlaying paludal sands. This formation is part of the largest continental loess area in Serbia, with thickness of $10 \div 20 \mathrm{~m}$, exceptionally, up to $30 \mathrm{~m}$. Accumulation of loess was carried out during the Pleistocene glacial periods when the winds brought fine silt which by diagenesis created loess.

In the loess mass, small vertical channels from rotten plants and small cracks due to shrinkage are present. Itcauses higher vertical than horizontal permeability, which allows rapid infiltration of precipitation in surface area. In dry state, loess has a high strength and low compressibility, however, highly porous layers of loess due to saturation lose structure, reduce volume and strength extremely. This loess feature is known as structural collapse or hydro-collapse, making it one of the meta-stable soils, which are very unfavourable in terms of foundation.

Double oedometer tests $[3 \div 6]$ were carried out on natural and saturated samples and they confirmed distinct collapse potential of the loess on the presented location.

The disturbance of samples from 2,5 m deep test pit was minimal. The deeper cylindrical samples $(\varnothing 100 \mathrm{~mm})$, from borings were taken by thin-walled Shelby tube with a very low area ratio $A_{\mathrm{r}}=5 \%$. Due to sampler quality the samples disturbance was also kept relatively low. 
Based on the results of laboratory testing of loess samples from depths between 1,0 and $12,0 \mathrm{~m}$, the following parameters were obtained (Tab. 1).

Table 1Geomechanical parameters of the loess

\begin{tabular}{|l|c|c|}
\hline \multicolumn{1}{|c|}{ Property } & Range & $\begin{array}{c}\text { Average } \\
\pm \text { St. Dev. }\end{array}$ \\
\hline USCS & CL, CI & \\
\hline Sand content (\%) & $9,0 \div 13,0$ & $11,1 \pm 1,4$ \\
\hline Silt content (\%) & $74,0 \div 83,0$ & $79,2 \pm 3,4$ \\
\hline Clay content (\%) & $6,0 \div 13,0$ & $9,8 \pm 2,9$ \\
\hline Specific gravity & 2,67 & \\
\hline Liquid limit (\%) & $25,3 \div 35,6$ & $29,5 \pm 3,6$ \\
\hline Plasticity index (\%) & $9,5 \div 15,8$ & $12,8 \pm 2,2$ \\
\hline Natural moisture (\%) & $6,5 \div 14,4$ & $10,8 \pm 3,3$ \\
\hline Consistency index & $1,0 \div 1,8$ & $1,3 \pm 0,25$ \\
\hline Dry unit weight (kN/m $\left.{ }^{3}\right)$ & $12,6 \div 14,1$ & $13,4 \pm 0,58$ \\
\hline Coefficient of porosity & $0,88 \div 1,05$ & $0,97 \pm 0,06$ \\
\hline Colloidal activity (\%) & $1,3 \div 1,8$ & \\
\hline Angle of shearing resistance & $25,0 \div 29,3$ & \\
\hline Cohesion (kPa) & $11,5 \div 35,0$ & \\
\hline Modulus number & $59,0 \div 68,0$ & \\
\hline Stress exponent & $28,0 * \div 36,0 *$ & \\
\hline Collapse potential (\%) & $0,57 \div 0,75$ & \\
\hline CPT (MPa) & $0,33 * \div 0,41^{*}$ & \\
\hline
\end{tabular}

* Saturated samples from depth of $1,5 \div 2,5 \mathrm{~m}$.

\section{Omission in foundation pit protection}

The geomechanical study that was done in 2009 stated that loess samples have a high collapse potential and that all necessary measures and technical solutions need to be taken during the construction and operation phase in order to prevent rain water, tap water or sewage from soaking the foundation soil over a long time period. Otherwise, depending on the level of soil saturation, additional uneven settlement should be expected.

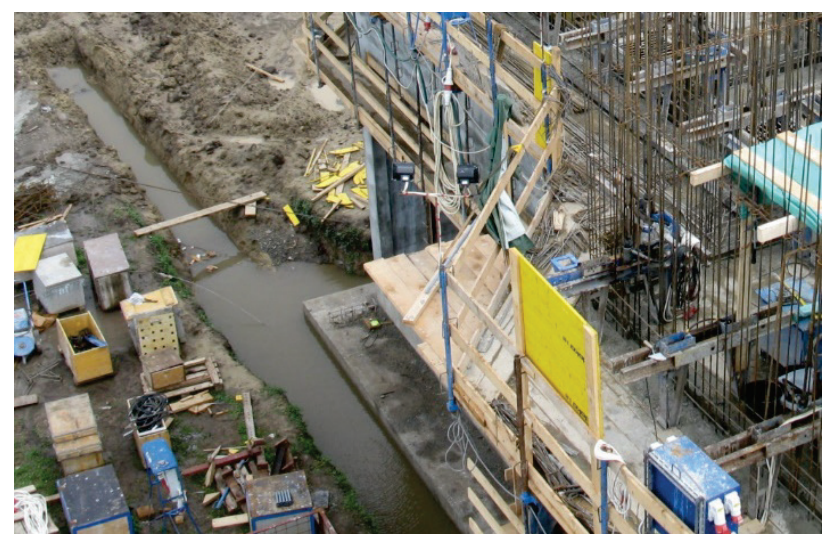

Figure1Heavy saturation of the foundation pit

Construction of the building began in late March 2010. During and after the excavation of the foundation pit, weather conditions were very unfavourable with a very large amount of rainfall resulting in difficult construction conditions. It should be noted, that the foundation pit, especially for the silo, was open and unprotected for a long period of time. The water infiltration was further facilitated through gravel-sand cushion, so in a short time the base of the pit had water several decimetres deep. The volume of flooding is shown in Figs. 1 and 2. This event reoccurred at the beginning of July. With few exceptions, water was always present in the foundation pit.

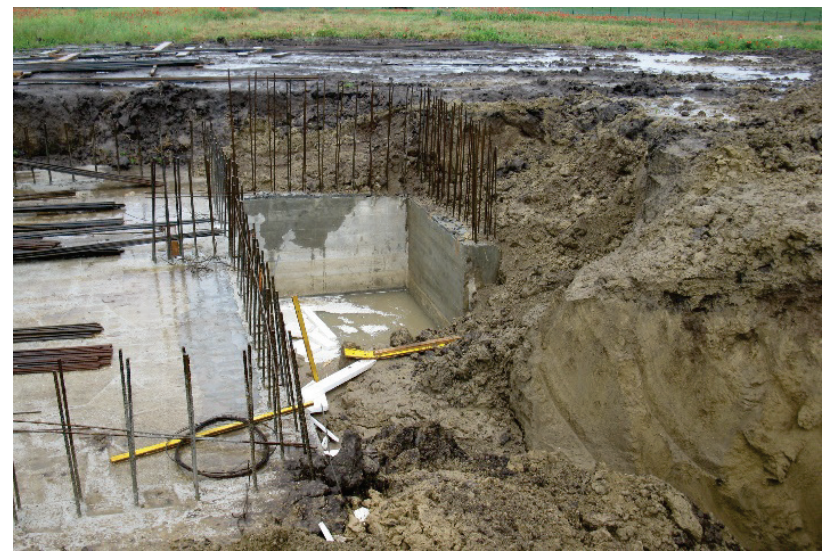

Figure 2 Saturation and sliding ground around the foundation pit

\section{Settlement estimation due to loading}

Reliable estimation of the size and the dynamics of soil settlement is very important, especially for very heavy objects, because, on the basis of settlements, the type of the foundation and the way that internal and external installation is connected is determined. The type of the foundation on the other hand significantly affects the costs.

For the settlement calculation, the soil compressibility at natural state was used without assessing the impact of loess hydro-collapse, assuming that all necessary steps during construction and operation phase will be taken to prevent soaking of the foundation. Bearing capacity is not a controlling criterion because it significantly overestimates the actual contact stresses under the silo and the mill.

Based on deformation parameters, loads and depth of the foundation $(1,2 \mathrm{~m})$, the average computed settlements are $136 \mathrm{~mm}$ for silo and $97 \mathrm{~mm}$ for the mill. Because of the structure's height and mat stiffness, the settlements are calculated in equivalent (Kany's) points. Calculations were carried out by the method of tangent modulus, based on the deformation parameters from oedometer test, according to:

$$
s=\int \mathrm{d} \varepsilon_{z}=\int \frac{1}{m \cdot a}\left[\left(\frac{p_{0}^{\prime}+\mathrm{d} \sigma_{z}^{\prime}}{p_{a}}\right)^{a}-\left(\frac{p_{0}^{\prime}}{p_{a}}\right)^{a}\right] \mathrm{d} z .
$$

To calculate the vector of mat settlements $\boldsymbol{s}$, moments and shear forces, the soil-mat-structure interactions were analysed. The soil was replaced by elastic supports. For external forces $\boldsymbol{Q}$, stiffness matrix of the structure $\boldsymbol{K}_{K}$, mat $\boldsymbol{K}_{P}$ and soil $\boldsymbol{K}_{T}$, the interaction equation is:

$\left(\boldsymbol{K}_{K}+\boldsymbol{K}_{P}+\boldsymbol{K}_{T}\right) \cdot \boldsymbol{s}=\boldsymbol{Q}$.

The matrix $\boldsymbol{K}_{T}$ represents the stiffness modulus of the elastic supports, which are determined as the ratio of the average contact stress and settlement by the Eq. (1). 
Due to approximate symmetry of the loads on the mat and soil homogeneity, the settlements are mostly uniform. According to valid national technical codes (SRPS), in the case of mat foundation under the entire building, on fine grain soil, without taking into account the settlement impact on the structure, the allowed design settlement is $\leq 10 \mathrm{~cm}$. In the case of larger settlements, the impact on the building stability and functionality must be considered. In this case the settlements are larger than $10 \mathrm{~cm}$, but due to symmetry and large structural stiffness they are uniform and acceptable from structural-technological point of view. Since deep foundations are more expensive, the shallow type was adopted, with a requirement as to completely prevent the possibility of dampening the foundation soil during the construction and operation phase of the facility.

\section{Observed settlements}

For settlement monitoring of the silo and the mill,12 geodetic marks were installed. The demanded accuracy of the settlement measurement was $\pm 0,5 \mathrm{~mm}$. In the project documentation, it was demanded that the fillment of the silo cells must be gradual and steady, with monitoring of the settlements during and after fillment. Since the loading of the stored mass is relatively large, the first filling of the silo is always critical because rapid and uneven loading of the cells can cause uneven settlements, while in saturated fine-grained soil undrained soil failure can occur.

At the mill, 6 geodetic marks $(1 \div 6)$ were embedded. All stayed intact except 1 that was damaged in the $4^{\text {th }}$ and restored in the $9^{\text {th }}$ measurement series. At the silo, 6 marks $(7 \div 12)$ were embedded. Settlements over time are shown in Figs. 3 and 4 for the mill and for the silo. The first filling of the silo was at the end of Oct. 2011. There were 20 measurements over the time period of 45 months [7].

The mean value and the standard deviation of the last observed settlements of the mill was $109 \pm 33 \mathrm{~mm}$, and of the silo it was $175 \pm 38 \mathrm{~mm}$.

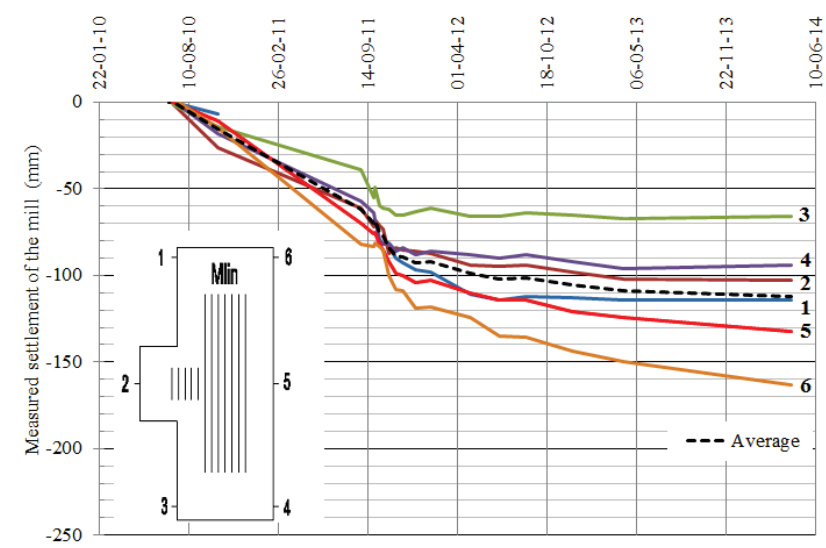

Figure 3 Measured settlements of the mill

The average observed settlement of the empty silo was $15 \mathrm{~mm}(28 \%)$ less than calculated, but for the last series of measurements for a full silo it was $39 \mathrm{~mm} \mathrm{(29}$ $\%$ ) higher. The average observed settlement of the mill for the last series was $12 \mathrm{~mm}(12 \%)$ higher than calculated.

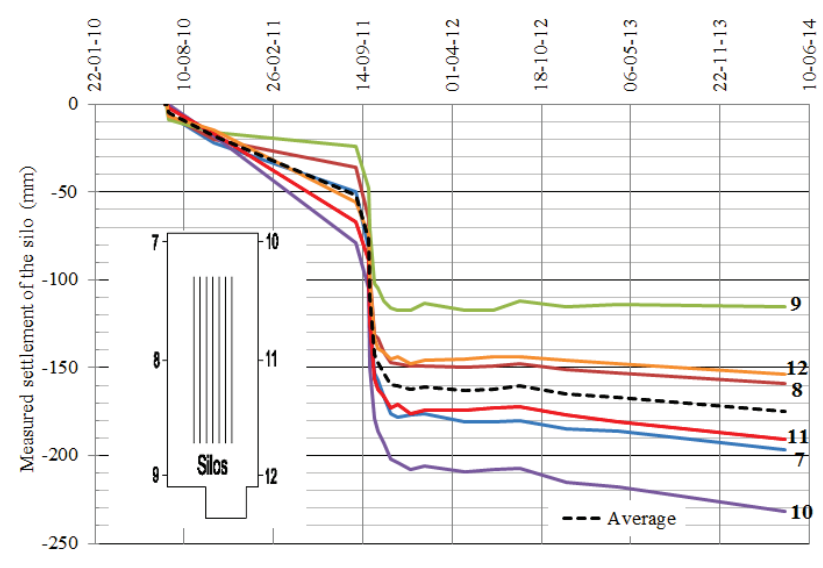

Figure 4 Measured settlements of the silo

After initial filling of the silo, symmetrically, cell by cell, the observed settlements were greater than the calculated, so the question arose regarding the cause of higher settlements, the expected settlements rate and the reduction of the silo capacity.

In this sense, the team of experts was formed with the task to analyse, in shortest time possible, the design and construction documents and to prepare a report, which will explain the cause of increased settlements, assess further development of the settlements and propose measures for prevention of undesirable consequences that would disable the normal functioning of the silo.

\section{The estimation of the precipitation on the location}

Since it is known that the calculated settlements based on standard geomechanical expressions are generally more or less conservative, and bearing in mind that the loess was intensively wetted, it was assumed that the major cause of higher settlements is the loess partial hydro-collapse. To assess the impact of intense rainfall in loess wetting, the expert's report used data from the national hydro-meteorological service. Fig. 5 shows the monthly and daily amount of rainfall for the continental regime, according to the hydro-meteorological station at Palić.

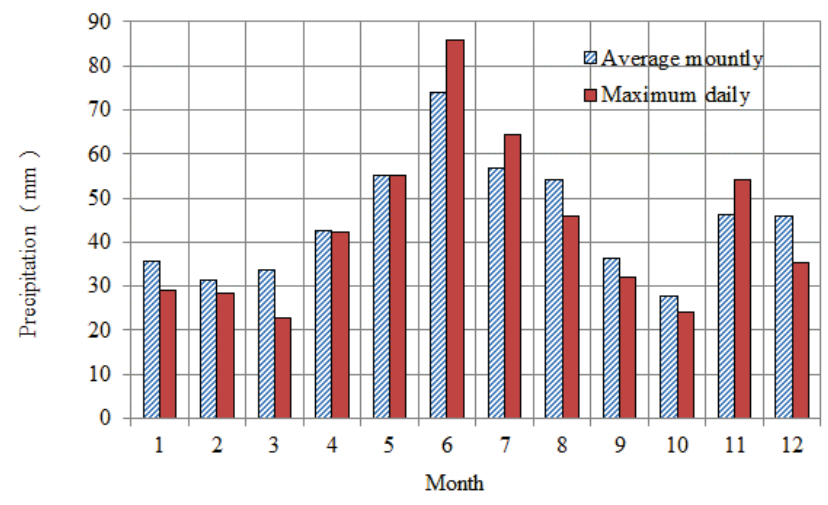

Figure 5 Amount of precipitation HMS - Palić

The data refers to the average hydrological year. It shows that the max. daily rainfall in June $\div$ July is $85 \div 64$ $\mathrm{mm}$. 


\section{Settlement estimation due to partial loess saturation}

According to the geomechanical study, the moisture of the loess grows with depth. At a depth of $2,0 \mathrm{~m}$, the natural moisture is $\approx 6,8 \%$, coefficient of porosity is 1,050 and saturation is 0,17 . At a depth of $12,0 \mathrm{~m}$, the natural moisture is $\approx 13,5 \%$, the coefficient of porosity is 0,880 and the saturation is $\approx 0,41$. The amount of water at a depth of $2,0 \mathrm{~m}$ is $871 / \mathrm{m}^{3}$ and at a depth of $12,0 \mathrm{~m}$ is 192 $1 / \mathrm{m}^{3}$, which is the approximate amount of $1 \div 2$ times the average monthly precipitation in June. It is obvious that longer and intense rainfall can significantly increase the soil moisture in an unprotected foundation pit, which can decrease strength and increase compressibility and settlements. The parameters for the settlement assessment due to wetting were adopted on the basis of double oedometer test on samples from 2,5 m deep test pit. The obtained results shown in Fig. 6, are consistent with similar tests at the broader loess locations in Vojvodina [8].

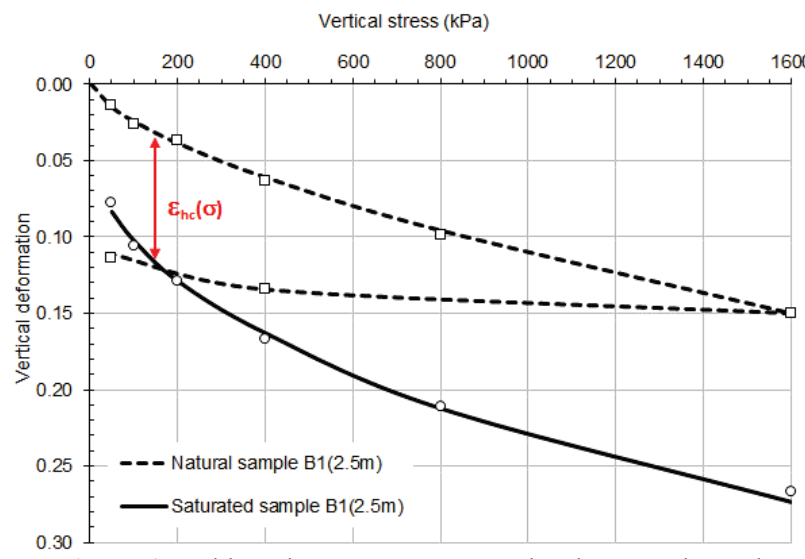

Figure 6 Double oedometer test on natural and saturated sample

Deformation parameters for undisturbed sample are $m=61,0$ and $a=0,64$, while for saturated one they are $m=$ 28,0 and $a=0,34$. According to Fig. 6, loess collapse potential at vertical pressure of $\sigma=100 \div 200 \mathrm{kPa}$, is estimated by:

$C_{\mathrm{P}}=\varepsilon_{\mathrm{hc}}(\sigma)=\frac{e_{\mathrm{dry}}(\sigma)-e_{\mathrm{sat}}(\sigma)}{1+e_{0}} \approx 0,096$

In the above equation, $\varepsilon_{\mathrm{hc}}$ is the vertical deformation due to hydro collapse, $e_{\text {dry }}$ and $e_{\text {sat }}$ are coefficients of porosity before and after saturation and $e_{0}$ is the initial coefficient of porosity. Potential severity of the hydro-collapse [9] can be usually estimated according to Tab. 2 .

Table 2 Potential severity of collapse

\begin{tabular}{|c|l|}
\hline Collapse potential $(\%)$ & \multicolumn{1}{|c|}{ Severity of problem } \\
\hline $0 \div 1$ & No problem \\
\hline $1 \div 5$ & Moderate trouble \\
\hline $5 \div 10$ & Trouble \\
\hline $10-20$ & Severe trouble \\
\hline$>20$ & Very severe trouble \\
\hline
\end{tabular}

The collapses of loess were studied by many authors. Holtz and Hilf [10] explained the collapse mechanism as a result of gradual or sudden decrease in capillary pressure to zero due to soil moisture increasing to saturation. Burland [11] attributed the collapse to the break-up of mechanism which ensures the stability of inter-particle contacts. Because of wetting, the negative pore water pressure or suction decreases and causes slippage and distortion of the grains. During drying below the shrinkage limit, water that remains in tight contact between the soil particles becomes tensioned so the effective stresses acting on the grains become larger than the total stress from external loads. In this way, the soil gains apparent strength. Mitchell [12] explained the collapse phenomenon due to weak bonding between the grains by thin clay or carbonate layer. Barden [13] stated 4 conditions required for collapse:

- Open, partially unstable, partially saturated soil fabric.

- High enough total stress, which ensures the metastable structure.

- Strong enough clay binder or other cementing layer to stabilize the structure in the dry state.

- Adding water to reduce suction and create collapse.

There are a number of sophisticated numerical methods for soil collapse simulation $[14,15,16]$ but in this paper, a relatively simple one is used for calculations of the collapse settlements. Beside the standard deformation and hydraulic parameters, the method required the moisture growth by depth as a result of wetting. Since the site measurements were impossible, the prediction of the moisture was based on the rainfall amount, soil hydraulic conductivity and retention capacity. To assess the increase of the soil moisture with depth due to surface wetting, the transient water flow through an unsaturated soil was performed [17]:

$\frac{\partial}{\partial x}\left(k_{x} \frac{\partial H}{\partial x}\right)+\frac{\partial}{\partial y}\left(k_{y} \frac{\partial H}{\partial y}\right)+q=m_{v} \gamma_{w} \frac{\partial H}{\partial t}$.

In the above equation, $H$ is the hydraulic potential, $k_{x}$ and $k_{y}$ are the soil horizontal and vertical unsaturated hydraulic conductivity, $q$ is the surface flux and $m_{v}$ is the slope of the storage curve (the function of the bulk soil moisture $\theta$ and matric suction $u_{a}-u_{w}$ ).

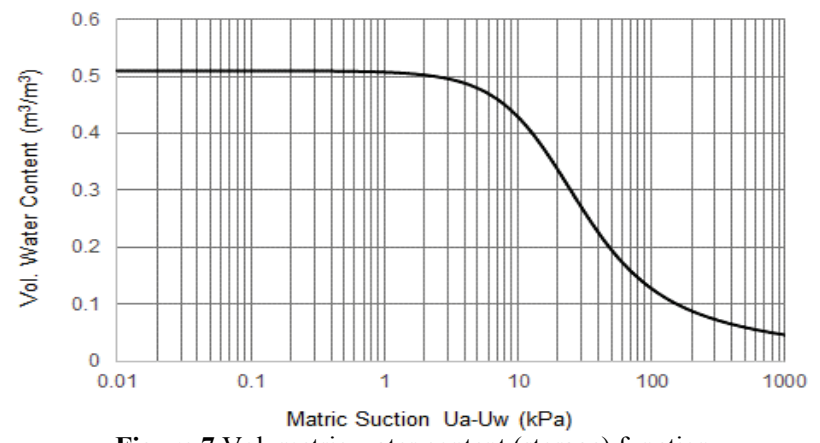

Figure 7 Volumetric water content (storage) function

Based on laboratory tests, the loess porosity at a depth of $2,0 \mathrm{~m}$ is 0,512 , the saturated hydraulic conductivity is $k_{x}=1,2 \times 10^{-7} \mathrm{~m} / \mathrm{s}$ and the hydraulic anisotropy is $k_{y} / k_{x} \approx 5$. The storage curve seen in Fig. 7 , is predicted using the basic properties of the silt-type material [19]. 
Unsaturated hydraulic conductivity of the soil (Fig. 8) is predicted from storage curve (Fig. 7) and its saturated hydraulic conductivity [19].

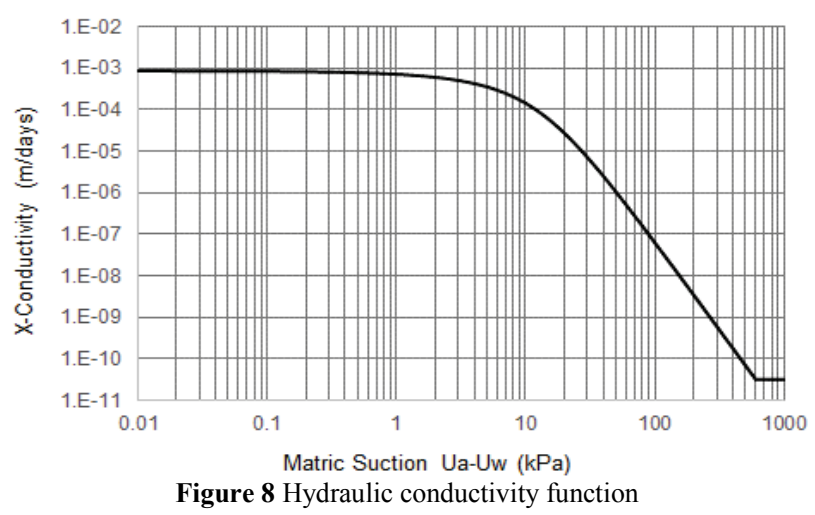

The loess is supposed to soak through the gravel-sand cushion for 3 months (April, May, June) by $60 \mathrm{~mm}$ of rain monthly. Evaporation is not considered, which means that the increase of the soil moisture will be on the upper bound.

Calculations according to Eq. (4) for the given boundary conditions are carried out by means of finite elements analyses, using the software GEOSTUDIO SEEP/W 2012 [20]. Since the total length and the width of the foundation pit is $50 \times 11 \mathrm{~m}$, the plane flow model was adopted. The $Y$-axis is along the symmetry of the cross section.

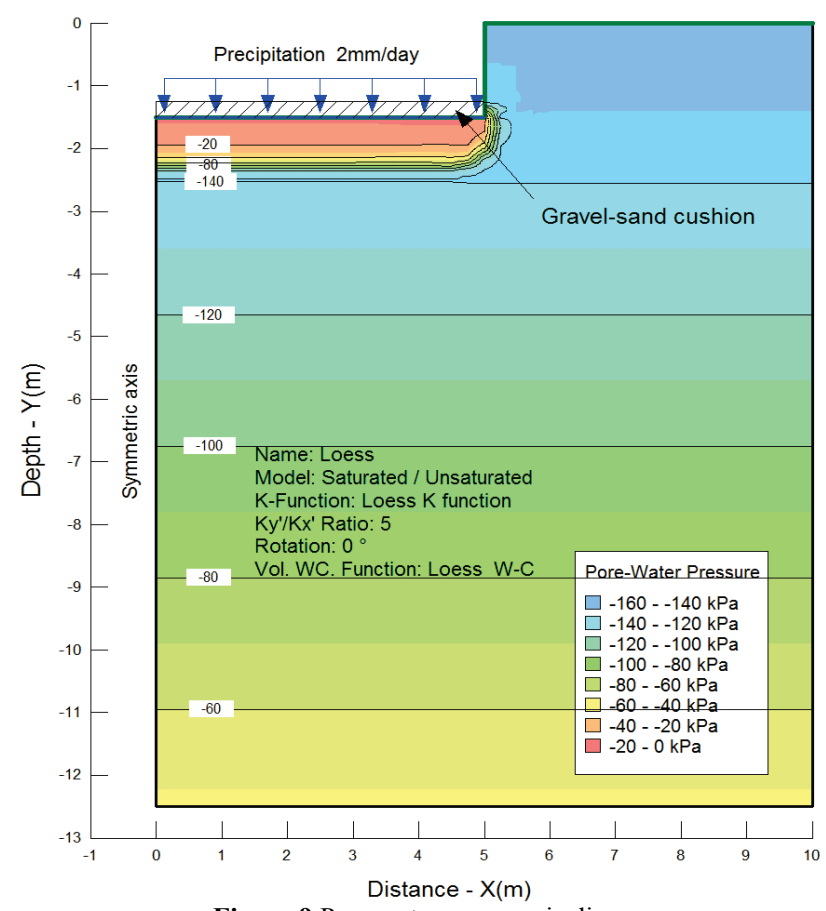

Figure 9 Pore water pressure isolines

Because the cross section is symmetric, only one half of the domain is used. The depth of the excavation is 1,5 $\mathrm{m}$, and the thickness of the gravel-sand cushion is $0,25 \mathrm{~m}$. The domain of the filtration is divided into finite elements with size $0,25 \times 0,25 \mathrm{~m}$. Convergence study showed that results with other finite element sizes $(0,5 \times 0,5 \mathrm{~m}$ and $0,15 \times 0,15 \mathrm{~m})$ result in negligible differences.
The initial suction in the loess at a depth of $2,0 \mathrm{~m}$ at natural moisture of $6,8 \%$, estimated from storage curve is $u_{a}-u_{w} \approx 150 \mathrm{kPa}$, and close to measured value by the filter paper method. At the depth of $12,0 \mathrm{~m}$, with the initial moisture of $13,5 \%$, the suction in the loess is $\approx 50$ $\mathrm{kPa}$.

The amount of precipitation at the foundation baseline is $2 \mathrm{~mm} /$ daily, or totally $0,18 \mathrm{~m}^{3}$ for April, May and June. The results of the pore water pressure estimation due to wetting of the foundation pit through a gravel-sand cushion over 90 days, are shown in Fig. 9.

The water from the flooded foundation pit infiltrates into deeper layers, decreasing suction and increasing hydraulic conductivity. Based on the results of transient flow analysis, the bulk soil moisture in time and depth are estimated (Fig. 10). The computational depth, above which a significant increase in soil moisture occurred is roughly $1,0 \mathrm{~m}$ below the foundation.

Using the collapse potential and the moisture gain versus depth, the vertical deformation of the soil layers and collapse settlement can be calculated.

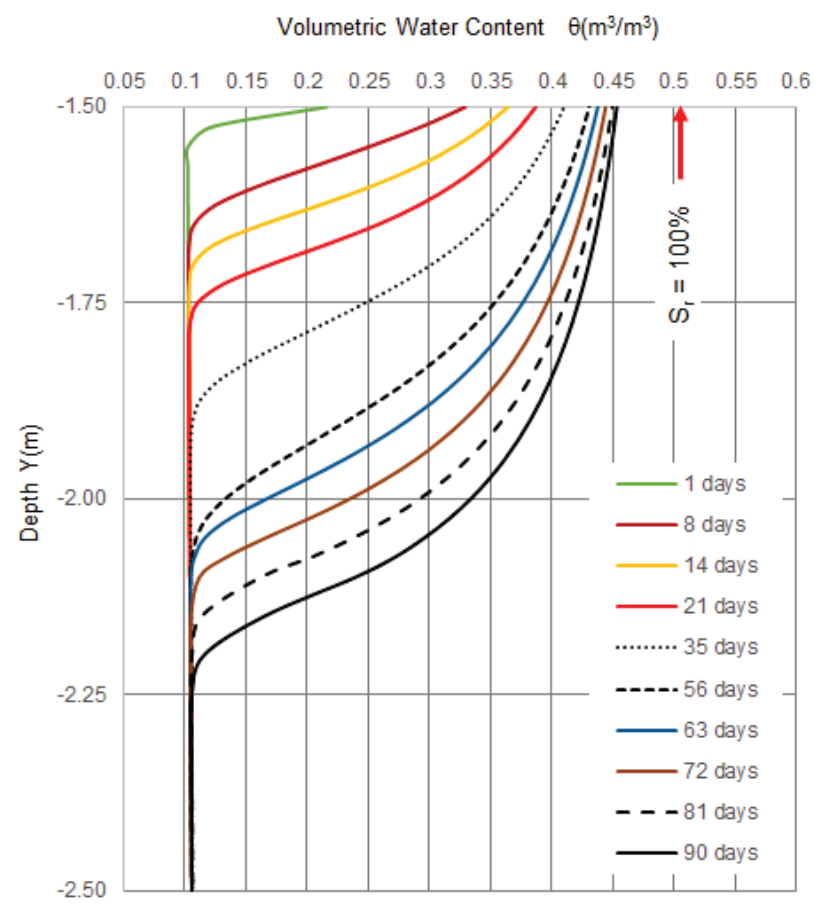

Figure 10 Isochrones of volumetric water content

Assuming that the vertical deformation due to partial hydro-collapse is proportional to the increase of moisture, the settlement of the wetted layer at the time $t$ is:

$s_{\mathrm{hc}}=\int \mathrm{d} \varepsilon_{\mathrm{hc}}=\int \frac{C_{\mathrm{P}}\left[\theta(z)-\theta_{0}(z)\right]}{S_{\mathrm{r}}^{*} \cdot n(z)-\theta_{0}(z)} \mathrm{d} z$.

Full collapse can even occur at moistures slightly less than full saturation $(0,95 \div 1,0)$. Based on the adopted values of the saturation $S_{\mathrm{r}}^{*}=0,95$ and collapse potential of $9,6 \%$, the vertical deformation versus depth is estimated, as presented in Fig. 11. Applying the numerical integration method to Eq. (5), the settlement caused by hydro collapse is $s_{\mathrm{hc}}=47 \mathrm{~mm}$. 


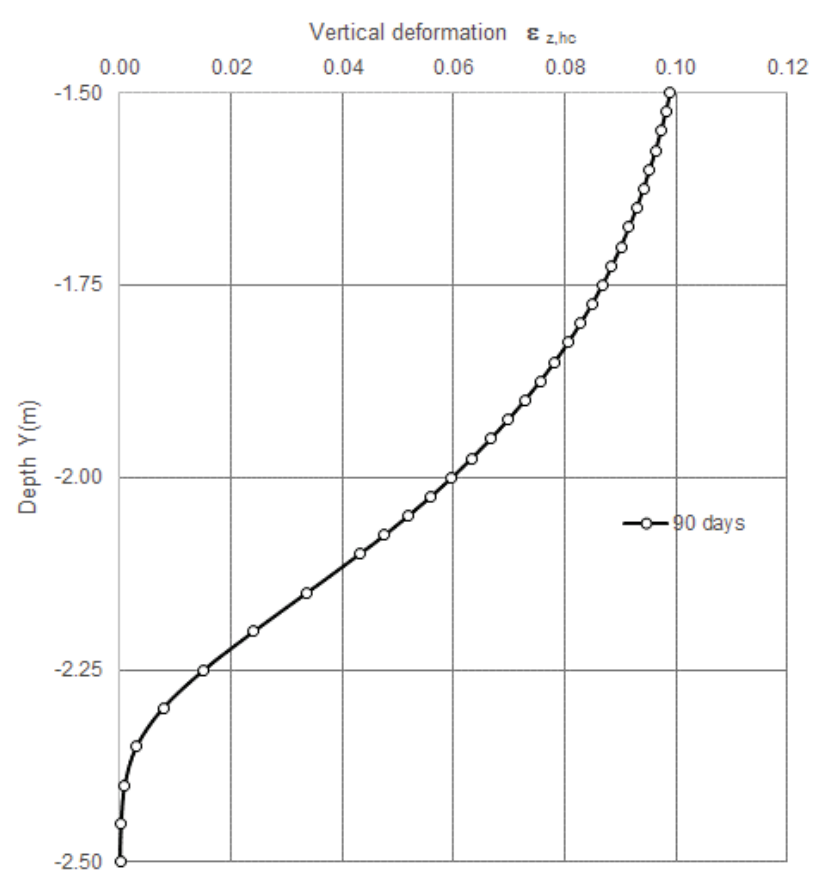

Figure 11 Vertical deformation caused by hydro-collapse

\section{Recommendations linked to increased settlements}

Bearing in mind the value of computed and observed settlements after the initial filling of the silo cells, it was necessary, in a very short time, to estimate the further rate of the settlements in order to propose appropriate measures to ensure the smooth function of the silo. The main goal of the user of the facility was continuous receiving, storing and processing of grain. The total computed settlements (initial compression, consolidation and partial collapse) of $183 \mathrm{~mm}$ were relatively large but uniform, still, the expert team concluded there is no functional dangers for the silo. In order to prevent further problems, the following was proposed:

- Continue to measure settlements once weekly within next month. Afterwards, depending on the settlements, once a month, once in 3 and once in 6 months.

- For each measurement, record the cells occupancy and calculate the differential settlements, alternate the discharging and charging regime of the cells in order to reduce differential settlements.

- Carry out emergency repair of damaged coating of the dilatation joints, in order to prevent the water reaching the subsoil and to cause additional wetting.

- Change the current design of the underground draining of the water from the nose to the sewer, with a surface discharge into gutter and their discharge from facility.

- Review and if necessary, repair the internal-external joints of the hydro-technical installations.

\section{Conclusion}

It should be noted that there is a large number of silos built in Vojvodina, on shallow foundation and on weak soil. In extreme cases observed settlements of these silos were up to $60 \mathrm{~cm} \mathrm{[21]} \mathrm{but} \mathrm{relatively} \mathrm{uniform.} \mathrm{Because} \mathrm{of}$ this uniformity, despite the large values of settlement, these silos have been in smooth operation for decades.

The observed settlements of presented silo were 115 $\div 232 \mathrm{~mm}$, with the mean value and standard deviation of $175 \pm 38 \mathrm{~mm}$. The relatively large differential settlements do not indicate unilateral inclination, but a certain distortion which up to this day did not cause visible damage. Geodetic measurements did not show noticeable vertical deviation of the walls.

Despite the average observed settlement being $75 \%$ above the allowable project settlement by the technical codes SRPS, the work of the silos remains smooth.

\section{References}

[1] EN-1256-I/2009: North-Engineering d.o.o Subotica. Glavni projekat za "PTP Julia mlin d.o.o." u Feketiću.

[2] EG-19/2009: Geoexpert d.o.o. Subotica. Geomehanicki elaborate za "PTP Julia mlin d.o.o." u Feketiću.

[3] Das, B. M. Principles of foundation engineering. $5^{\text {th }}$ ed. USA: Brooks/Cole, 2004.

[4] Delage, P.; Cui, Y. J.; Antoine, P. Geotechnical problems related with loess deposits in Northern France. // Proc. of Int. Conf. on Problematic Soils, Eastern Mediterranean University, Famagusta, Cyprus, 2(2005), pp. 517-540.

[5] Sun, D. A.; Sheng, D.; Xu, X. F. Collapse Behavior of Unsaturated Compacted Soils. // Canadian Geotechnical Journal. 44(2006), pp. 673-686. DOI: 10.1139/t07-023

[6] Meier, C.; Boley, C.; Zou, Y. Collapse and deformation of alluvial loess soil from Afghanistan. // Geotechnics of Soft Soil: Focus on Ground Improvement, Proceedings of the $2^{\text {nd }}$ International Workshop / Glasgow, 2008, pp 269-273.

[7] E5/2014: Geotop S. R. Backa Topola. Elaborat o opazanju repera na objektu"PTP Julia mlin d.o.o." u Feketiću.

[8] Otterbein, K. Szerkezetes talaj sziláardsági es alakváltozás anizotrópiájának vizsgálata. Doktori értekezés. Budapesti Müszaki Egyetem, ÉMK, Budapest, 1982.

[9] Jennings, J.E.; Knight, K. A guide to construction on or with materials exhibiting additional settlement due to collapse of grain structure. // Proceedings of the $6^{\text {th }}$ Regional Conference for SouthAfrica on Soil Mechanics and Foundation Engineering/ Durban. 1(1975), pp. 99-105.

[10] Holtz, W. G.; Hilf, J. W. Settlement of soil foundations due to saturation. // Proceedings of the $5^{\text {th }}$ International Conference on Soil Mechanics and Foundation Engineering / Paris, 1(1961), pp. 673-679.

[11] Burland, J. B. Some aspects of the mechanical behavior of partly saturated soils. In Moisture Equilibria and Moisture Changes in Soils beneath Covered Areas. // Butterworths, Sydney, Australia. (1965), pp. 270-278.

[12] Mitchell, J. K. Fundamentals of Soil Behavior $2^{\text {nd }}$ ed. John Wiley \& Sons, Inc., New York, 1993.

[13] Barden, L.; McGown, A.; Collins, K. The collapse mechanism in partly saturated soil. // Engineering Geology, Amsterdam. 7(1973), pp. 49-60. DOI: 10.1016/00137952(73)90006-9

[14] Sun, D. A.; Sheng, D.; Sloan, S. W. Elastoplastic modelling of hydraulic and stress-strain behavior of unsaturated soil. // Mechanics of Materials. 39 (2006), pp. 212-221. DOI: 10.1016/j.mechmat.2006.05.002

[15] Huan L.; Jing C. J.; Pan H. Z.; Guo B. Y.; She, J. S. A constitutive model for collapsible material: Applications. // Advanced Materials Research. 511, (2012), pp. 122-125. DOI: 10.4028/www.scientific.net/AMR.511.122

[16] Jie, Y.; Jian, L.; Hua, Y. Non-linear K-G constitutive model for unsaturated loess. $/ / 4^{\text {th }}$ Int. Conference on Unsaturated Soils. Carefree, Arizona/2006, pp. 2004-2014. DOI: 10.1061/40802(189)169 
[17] Fredlund, D. G. Unsaturated soil mechanics in engineering practice. // Journal of Geotechnical and Geoenviromental Engineering. 132, 3(2006), pp. 286-321. DOI: 10.1061/(ASCE)1090-0241(2006)132:3(286)

[18] Aubertin, M.; Mbonimpa, M.; Bussiere, B.; Chapuis, R. P. A model to predict the water retention curve from basic geotechnical properties. // Canadian Geotechnical Journal. 40, 6(2003), pp. 1104-1122. DOI: 10.1139/t03-054

[19] Van Genucthen, M. Soil evaporative fluxes for geotechnical engineering problems. Ph.D. Thesis. Univ. of Saskatchewan, Saskatoon, Canada, 1990.

[20] Seepage modeling with SEEP/W.2013 ed. An engineering methodology. GEO-SLOPE International Ltd., 2013.

[21] Gostović, M.; Santrač, P. Merenje sleganja poljoprivrednih objekata. Projekat razvoja naučne discipline. SIZ za Nauku SAPV, Novi Sad. Građevinski fakultet Subotica, 19821985.

\section{Authors' addresses}

Prof. Petar Santrač, dipl. ing., MSc, PhD, CEng

Univerzitet u Novom Sadu, Građevinski fakultet Subotica Kozaračka 2a, 24000 Subotica, Srbija

E-mail: santrac@gf.uns.ac.rs

Željko Bajić, dipl. ing., MSc

Univerzitet u Novom Sadu, Građevinski fakultet Subotica Kozaračka 2a, 24000 Subotica, Srbija

E-mail: bajic@gf.uns.ac.rs

Slobodan Grković, dipl. ing., MSc

Univerzitet u Novom Sadu, Građevinski fakultet Subotica Kozaračka 2a, 24000 Subotica, Srbija

E-mail: most@gf.uns.ac.rs

Prof. Danijel Kukaras, dipl. ing., MSc, PhD, CEng

Univerzitet u Novom Sadu, Građevinski fakultet Subotica Kozaračka 2a, 24000 Subotica, Srbija

E-mail: dkukaras@gf.uns.ac.rs

Ass. Prof. Ivan Hegediš, dipl. ing., MSc, PhD, AEng

Univerzitet u Novom Sadu, Građevinski fakultet Subotica Kozaračka 2a, 24000 Subotica, Srbija

E-mail: hege@gf.uns.ac.rs 